\title{
Low sensitivity of polymerase chain reaction for diagnosis of tuberculous meningitis in southeastern Brazil
}

\author{
Baixa sensibilidade da reação em cadeia da polimerase para o diagnóstico \\ de meningite tuberculosa no sudeste do Brasil
}

\begin{abstract}
Vânia Maria Sabadoto Brienzeㄹ, Ângela Pedroso Tonon', Fabrício José Tarelho Pereira1, Elisabete Liso', Waldir Antônio Tognola ${ }^{1}$, Manoel Armando Azevedo dos Santos ${ }^{2}$ and Marcelo Urbano Ferreira ${ }^{2}$
\end{abstract}

\begin{abstract}
Two polymerase chain reaction (PCR) protocols showed low sensitivity (36\% and 53\% for TB AMPLICOR and MPB64 nested PCR, respectively), when compared with classic microbiological methods (73\% and 54\% for Ziehl-Neelsen staining and culture, respectively), in the diagnosis of tuberculous meningitis in 91 patients in southeastern Brazil. Only three PCR-positive, microbiologically negative patients were found. Analysis of sequential cerebrospinal fluid samples by nested PCR detected Mycobacterium tuberculosis DNA up to 29 days after the introduction of antituberculosis chemotherapy.
\end{abstract}

Key-words: Diagnosis of tuberculous meningitis. PCR. Mycobacterium tuberculosis.

Resumo Dois protocolos de reação em cadeia da polimerase (PCR) apresentaram baixa sensibilidade (36\% e 53\%, respectivamente), para TB AMPLICOR e PCR aninhado baseado no gene MPB64), quando comparados aos métodos microbiológicos clássicos (73\% e 54\% respectivamente para baciloscopia e cultura), no diagnóstico de meningite tuberculosa em 91 pacientes do sudeste do Brasil. Somente três pacientes apresentaram $P C R$ positiva e microbiologia negativa. $A$ análise de amostras seqüenciais de líquor com a PCR aninhada detectou DNA de Mycobacterium tuberculosis até 29 dias após a introdução de tratamento.

Palavras-chaves: Diagnóstico da meningite tuberculosa. PCR. Mycobacterium tuberculosis.

Tuberculosis is responsible for over two million deaths each year across the world, and Brazil is one of the 22 high-burden countries that together report $80 \%$ of new cases world-wide. The situation is further complicated by the spread of HIV/AIDS and the emergence of multi-drug resistance among local Mycobacterium tuberculosis strains ${ }^{16}$. Around 90,000 new cases are reported yearly in Brazil, more than half of them involving patients living in the southeastern region of the Country. Almost $15 \%$ of all patients with newly diagnosed M. tuberculosis infection in São Paulo, southeast Brazil, are HIV-infected ${ }^{17}$. Pulmonary tuberculosis is by far the most common clinical presentation of symptomatic M. tuberculosis infection, but extrapulmonary involvement, such as meningitis, remains a significant cause of morbidity, especially among HIV-infected patients ${ }^{9}$. Bacteriological diagnosis of tuberculous meningitis relies on the microscopic identification of acidfast bacilli (AFB) on smears, and culture of mycobacteria on solid or liquid media. Microscopy is a simple and rapid screening test, but lacks sensitivity. Routine culture takes four to eight weeks to yield positive results. The radiometric BACTEC 460 TB system (Becton Dickinson) represents an important alternative to standard culture, since it requires only two weeks to detect most positive specimens ${ }^{1}$, but the high cost limits its availability in most referral hospitals in developing countries.

The need for a rapid diagnosis has led to the assessment of several polymerase chain reaction (PCR)based procedures for detection of $M$. tuberculosis DNA in cerebrospinal fluid (CSF) samples. The sensitivity of these molecular methods has been reported to vary between $33 \%{ }^{15}$ and $90.5 \%{ }^{13}$, and therefore the role of PCR in routine diagnosis remains unclear ${ }^{4}$, especially

\footnotetext{
1. Departamento de Doenças Infecciosas e Parasitárias da Faculdade de Medicina de São José do Rio Preto, São José do Rio Preto, SP; 2. Laboratório de Parasitologia do Instituto de Ciências Biomédicas da Universidade de São Paulo, São Paulo, SP.

Financial support: Fundação Faculdade Regional de Medicina (FUNFARME), UNDP/World Bank/World Health Organization Special Program for Research and Training in Tropical Diseases, CNPq and Fundação de Amparo à Pesquisa do Estado de São Paulo (FAPESP).

Address to: Dr. Marcelo U. Ferreira. Deptํ de Parasitologia/ICB/USP. Av. Prof. Lineu Prestes 1374, 05508-900 São Paulo, SP, Brazil.

Tel: 5511 3818-7273: Fax: 5511 3818-7417.

e-mail:muferrei@usp.br

Recebido para publicação em 2/8/2000.
} 
in resource-poor settings. Here we have examined the performance of two PCR-based methods, a commercially available kit (TB AMPLICOR, Roche Diagnostic Systems) and a nested PCR described by Liu and colleagues ${ }^{13}$, in the diagnosis of tuberculous meningitis in a tertiary care hospital in southeastern Brazil.

This study was performed at the Hospital de Base, a 600-bed teaching hospital situated in São José do Rio Preto, São Paulo State. A total of 105 CSF samples were obtained prospectively, between April 1996 and February 2000, from 91 patients with suspected meningitis (mean age, 33 years; range: 3 months-61 years). More than one CSF sample was available for 10 patients, and for 5 of them samples were also collected after the introduction of chemotherapy for tuberculosis. Sixty-six (73\%) patients had serologically confirmed HIV infection (mean CD4 cell count, $81.2 / \mathrm{ml}$; range: $2-384 /$ $\mathrm{ml}$ ). All patients were grouped according to a set of clinical and laboratorial criteria, essentially as described and validated by Ahuja and colleagues ${ }^{2}$ : (A) presence of fever and headache lasting more than 14 days, with or without vomiting, alteration of sensorium or focal deficit; (B) presence of acid-fast bacilli (AFB) on CSF smears stained with Ziehl-Neelsen (ZN) or culture (B1), and absence of other bacteria and fungi, as well as malignant cells, in CSF (B2); (C) CSF pleocytosis with more than 10 cells $/ \mathrm{ml}$ (more than 60\% lymphocytes) (C1), and CSF concentrations of protein greater than $0.6 \mathrm{mg} / \mathrm{ml}(\mathrm{C} 2)$ and of glucose less than $60 \%$ of the corresponding blood level (C3); (D) evidence of extraneural tuberculosis. Five groups were defined as different combinations of these criteria: (1) definite tuberculous meningitis $(A+B 1+B 2),(2)$ highly probable tuberculous meningitis $(A+B 2+C 1+C 2+C 3+D)$, (3) probable tuberculous meningitis $(A+B 2+$ two of the criteria $\mathrm{C} 1, \mathrm{C} 2, \mathrm{C} 3$ or D), (4) possible tuberculous meningitis $(A+B 2+$ one of the criteria $C 1, C 2, C 3$ or $D),(5)$ other disease (absence of $A$ or B2).

CSF samples (about $12 \mathrm{ml}$ ) were divided into three portions. One aliquot was sent to the CSF laboratory of Hospital de Base for cytology, biochemistry, bacterioscopy and culture for M. tuberculosis and other bacteria using standard methods ${ }^{3}$. The second portion was sent to the Laboratory of Mycobacteria, at the Department of Microbiology of the University of São Paulo, in São Paulo, for DNA extraction and amplification with the TB AMPLICOR kit. This test targets a speciesspecific sequence within the small sub-unit (16S) ribosomal RNA (rRNA) gene from M. tuberculosis. CSF samples were stored at $-20^{\circ} \mathrm{C}$, and DNA extraction was performed as recommended for respiratory specimens, according to the manufacturer's instructions. Briefly, $500 \mathrm{ml}$ of wash solution were added to $100-\mathrm{ml}$ CSF aliquots, the mixture was vortexed and centrifuged (12,500 $\mathrm{g}$ for $10 \mathrm{~min})$. Supernatants were aspirated, and $100 \mathrm{ml}$ of lysis reagent was added to the pellet. The samples were then vortexed and incubated for $45 \mathrm{~min}$ at $60^{\circ} \mathrm{C}$. Next, the samples were centrifuged $(12,500 \mathrm{~g}$ for $10 \mathrm{~s}$ ), and $100 \mathrm{ml}$ of neutralization reagent were added, followed by vortexing. Fifty microliters of extracted DNA templates were used in PCR. Amplification was performed exactly as recommended by the manufacturer, using a GeneAmp System 9600 thermal cycler (Perkin-Elmer). The amplification products were incubated with $100 \mathrm{ml}$ of denaturation solution, and 25 $\mathrm{ml}$ aliquots of denaturated samples were transferred to the wells of microtiter plates coated with a probe that targets a $M$. tuberculosis-specific sequence within the PCR product. Internal positive and negative controls were included in all experiments. Due to budget limitations, only 46 samples were tested with AMPLICOR kits, and no sample was re-tested, regardless of the occurrence of discordant results between PCR-based and microbiological diagnoses.

The third CSF aliquot $(200-500 \mathrm{ml})$ was sent to the Laboratory of Molecular Parasitology, at the Faculty of Medicine of São José do Rio Preto, for DNA extraction and amplification by a nested PCR protocol that targets the species-specific MPB 64 protein gene from M. tuberculosis ${ }^{13}$. CSF samples were stored at $-20^{\circ} \mathrm{C}$ until DNA extraction. Template DNA was prepared from $200-\mathrm{ml}$ aliquots of CSF, which were incubated with protease $\mathrm{K}(20 \mathrm{mg} / \mathrm{ml}$ in a buffer containing $12 \mathrm{mM}$-Tris$\mathrm{HCl} \mathrm{pH}$ 8.0, 6mM EDTA and $0.6 \%$ SDS) for 3 hours at $56^{\circ} \mathrm{C}$, and purified in GFX columns (Amersham Pharmacia Biotech) according to the manufacturer's instructions. Two rounds of PCR amplification were performed in a Genius thermal cycler (Techne). The first round used the pair of external primers (here named MPB1 and MPB2) originally described by Shankar and colleagues ${ }^{20}$, while the second round used the internal primers (here named MPB3 and MPB4) designed by Liu and colleagues ${ }^{13}$. All primers were supplied by Gibco, and their sequences were given in the original publications. PCR mixtures included $5 \mathrm{ml}$ of extracted DNA or $1 \mathrm{ml}$ of first PCR product, $0.4 \mathrm{mM}$ of each primer, $200 \mathrm{mM}$ of each dNTP, and $0.75 \mathrm{U}$ of Taq polymerase (Amersham Pharmacia Biotech) in a final volume of $25 \mathrm{ml}$. In the first PCR, the mixture was incubated for $5 \mathrm{~min}$ at $95^{\circ} \mathrm{C}$, followed by 35 cycles of $94^{\circ} \mathrm{C}$ for $1 \mathrm{~min}$, $50^{\circ} \mathrm{C}$ for $1 \mathrm{~min}$ and $72^{\circ} \mathrm{C}$ for $1.5 \mathrm{~min}$, and a final incubation at $72^{\circ} \mathrm{C}$ for $10 \mathrm{~min}$. The program for the 25 cycles of nested PCR was $94^{\circ} \mathrm{C}$ for $1 \mathrm{~min}, 55^{\circ} \mathrm{C}$ for $1 \mathrm{~min}$ and $72^{\circ} \mathrm{C}$ for $1.5 \mathrm{~min}$, followed by a final incubation at $72^{\circ} \mathrm{C}$ for $10 \mathrm{~min}$. Amplification reagents and PCR products were handled in different laboratories using pipettes equipped with aerosol-resistant filter tips, in order to prevent carry-over contamination. The 200-bp amplification product was resolved by $1.5 \%$ agarose gel electrophoresis, stained with ethidium bromide and visualized under UV transillumination. Laboratory personnel was unaware of microbiological diagnosis at the time when the first PCR experiments were performed, but later all samples showing discordant results between microscopy and PCR were re-tested using, whenever possible, newly extracted DNA 
templates. A given sample was considered positive if M. tuberculosis DNA was detected in at least one test.

Table 1 shows that both PCR-based approaches had a relatively low sensitivity in detecting $M$. tuberculosis (respectively $36 \%$ and $53 \%$ for AMPLICOR and nested PCR), when compared with routine microbiological methods (respectively $73 \%$ and $54 \%$ for $\mathrm{ZN}$ staining and culture). Additionally, nested PCR was positive for one HIV-infected patient classified as having highly probable tuberculous meningitis (two CSF samples obtained on different occasions yielded concordant nested PCR results). Both nested PCR and AMPLICOR were also positive for an HIV-negative patient with probable tuberculous meningitis who was empirically given

Table 1- Proportion of cerebrospinal fluid samples that were positive by standard microbiological methods and polymerase chain reaction (AMPLICOR and MPB 64 nested PCR), according to the clinical diagnosis.

\begin{tabular}{|c|c|c|c|c|}
\hline Diagnosis & Ziehl-Neelsen stained smear & Culture & AMPLICOR & MPB 64 nested PCR \\
\hline Definite tuberculous meningitis $^{\mathrm{a}}$ & $11 / 15^{\mathrm{b}}(73 \%)^{\mathrm{c}}$ & $7 / 13(54 \%)$ & $4 / 11(36 \%)$ & $8 / 15(53 \%)$ \\
\hline Highly probable tuberculous meningitis ${ }^{d}$ & $0 / 4$ & $0 / 4$ & $0 / 0$ & $2 / 4(50 \%)$ \\
\hline Probable tuberculous meningitis $^{e}$ & $0 / 15$ & $0 / 15$ & $1 / 6(17 \%)$ & $1 / 15(7 \%)$ \\
\hline Possible tuberculous meningitis & $0 / 13$ & $0 / 13$ & $0 / 8$ & $1 / 12(8 \%)$ \\
\hline Other diseases ${ }^{e}$ & $0 / 51$ & $0 / 51$ & $1 / 17(6 \%)$ & $0 / 50$ \\
\hline Total & $11 / 98$ & $7 / 96$ & $6 / 42$ & $11 / 96$ \\
\hline
\end{tabular}

${ }^{2}$ Two patients provided two microbiologically positive samples. Microbiologically negative samples from patients with proven tuberculosis were not included

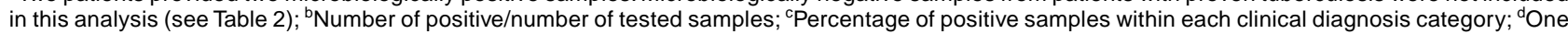
patient provided two samples, that were both positive by MPB 64 nested PCR alone; ${ }^{\mathrm{e} T w o}$ patients provided two samples, that were negative by all methods.

specific chemotherapy. Furthermore, an HIV-negative patient with confirmed pulmonary tuberculosis and possible tuberculous meningitis was positive by nested PCR only. Thus, three PCR-positive and microbiologically negative patients were identified, suggesting that PCR was able to identify a quite limited number of additional cases missed by microbiological methods. We interpreted this relatively poor diagnostic performance as resulting from: (1) low number of organisms present in CSF samples, that were below the detection threshold of our tests; (2) presence of DNA polymerase inhibitors in CSF samples ${ }^{21}$, or (3) presence of mycobacteria other than M. tuberculosis in some AFB-positive CSF samples, especially among HIVinfected patients. To examine the first hypothesis, we assessed the detection threshold of nested PCR by testing serial dilutions of purified DNA from $M$. tuberculosis culture. In these experiments, we were able to detect $0.2 \mathrm{pg}$ of $M$. tuberculosis DNA, which corresponds to approximately 40 organisms ${ }^{18}$. Given the sample volume used in PCR, this corresponds to approximately 800 organisms per $\mathrm{ml}$ of CSF. Microscopical detection of AFB on standard $\mathrm{ZN}$-stained smears usually requires between 5,000 to 10,000 organisms per $\mathrm{ml}$ of CSF, and a successful culture requires usually the presence of 10 to 100 mycobacteria in the sample ${ }^{5}$. However, a previous study $^{7}$ showed that most culture-positive CSF samples had fewer than 10 mycobacteria per $\mathrm{ml}$. These data suggest that substantially larger sample volumes should be processed in order to improve the sensitivity of PCR protocols ${ }^{11}$, including AMPLICOR, which has been usually performed with $100 \mathrm{ml}^{\circ}$ of $\mathrm{CSF}^{6}$ (and this study).

To address the second hypothesis, purified M. tuberculosis DNA was diluted in PCR templates prepared with CSF from 17 patients with either clinically suspected or microbiologically confirmed infection, but with negative nested PCR results. In all cases, it was possible to amplify $M$. tuberculosis DNA in these samples, suggesting that the presence of polymerase inhibitors played no major role in determining negative results. The authors have not performed a similar analysis for AMPLICOR-negative samples, but equivalent results for CSF samples had been reported in a previous analysis of this kind ${ }^{21}$, suggesting that the presence of polymerase inhibitors in the CSF does not represent as major limiting factor for amplification of M. tuberculosis DNA. The third hypothesis regards atypical mycobacteria, that have occasionally been detected as a cause of meningitis in immunocompromised patients ${ }^{8}{ }^{10}$. Since the study population included a large proportion of HIV-infected patients with low CD4 cell counts, and the target sequences of both PCR procedures are narrowly species-specific, the authors could not rule out the possibility that some false-negative results originated from the presence of atypical mycobacteria in AFBpositive patients. Further microbiological studies are required to address this issue.

At least one AMPLICOR-positive sample may be classified as a false-positive result (Table 1), since the patient did not meet clinical diagnostic criteria for tuberculous meningitis and fully recovered without specific chemotherapy. This patient was negative by nested PCR. This false-positive result may have originated from either carry-over contamination during PCR or from cross-reaction with non-mycobacterial DNA. No result may be surely considered as falsepositive among those obtained with our nested PCR. Interestingly, a recent comparison ${ }^{12}$ showed that a PCR targeting the MPB 64 gene was considerably more specific than reactions based on the $65 \mathrm{kDa}$ heat shock protein (HSP) gene and the repeated sequence IS6110.

Analysis of sequential CSF samples from five patients revealed that nested PCR was able to detect 
M. tuberculosis DNA up to 29 days after starting antituberculosis chemotherapy (Table 2), suggesting that PCR may be useful when patients had been given empirical treatment and standard microbiological tests ware negative. Despite this, the role of PCR in the diagnosis of tuberculous meningitis in resource-poor countries remains controversial ${ }^{6}{ }^{19}$. To the authors' knowledge, only one previous paper on this subject had been published in Brazil. Machado and colleagues amplified a fragment of the $65 \mathrm{kDa}$ HSP gene in 7 of 10 patients with suspected $M$. tuberculosis meningitis and in none of 10 patients with other infections ${ }^{14}$. Sample volumes used for PCR analysis were not described ${ }^{14}$. Further studies are clearly needed to evaluate the performance of PCR in different clinical settings, including empirically treated patients, before the role of this technique in routine diagnosis of tuberculous meningitis in Brazil may be established.

Table 2- Results of standard microbiological analyses and polymerase chain reaction (AMPLICOR and MPB 64 nested PCR) in sequential cerebrospinal fluid samples collected from five patients with proven tuberculous meningitis who were given specific chemotherapy.

\begin{tabular}{|c|c|c|c|c|}
\hline $\begin{array}{l}\text { Patient number } \\
\text { date of sample collection }\end{array}$ & en stained smear & Culture & AMPLICOR & MPB 64 nested PCR \\
\hline \multicolumn{5}{|l|}{ Patient \# 3} \\
\hline before treatment & negative & negative & negative & positive \\
\hline 6 days after starting treatment & positive & negative & negative & positive \\
\hline 13 days after starting treatment & negative & negative & negative & negative \\
\hline 15 months after starting treatment & negative & negative & negative & negative \\
\hline \multicolumn{5}{|l|}{ Patient \# 14} \\
\hline before treatment & negative & negative & negative & positive \\
\hline 3 days after starting treatment & positive & negative & positive & positive \\
\hline \multicolumn{5}{|l|}{ Patient \# 76} \\
\hline before treatment & negative & positive & negative & negative \\
\hline 29 days after starting treatment & negative & negative & not done & positive \\
\hline 120 days after starting treatment & negative & negative & not done & negative \\
\hline \multicolumn{5}{|l|}{ Patient \# 81} \\
\hline 5 days after starting treatment & positive & not done & negative & negative \\
\hline 7 days after starting treatment & positive & not done & negative & negative \\
\hline 19 days after starting treatment & negative & not done & not done & positive \\
\hline \multicolumn{5}{|l|}{ Patient \# 124} \\
\hline 6 days after starting treatment & positive & positive & not done & negative \\
\hline 14 days after starting treatment & negative & positive & not done & negative \\
\hline
\end{tabular}

\section{REFERENCES}

1. Abe C, Hosojima S, Fucosawa Y, Kazumi Y, Takahashi M, Hirano $\mathrm{K}$, Mori T. Comparison of MB-Check, BACTEC, and egg-based media for recovery of mycobacteria. Journal of Clinical Microbiology 30: 878-881, 1992.

2. Ahuja GK, Mohan KK, Prasad K, Behari M. Diagnostic criteria for tuberculous meningitis and their validation. Tubercle and Lung Disease 75: 149-152, 1994.

3. American Thoracic Society. Diagnostic standards and classification of tuberculosis. American Review of Respiratory Diseases 142: 725-735, 1990.

4. American Thoracic Society. Rapid diagnostic tests for tuberculosis: what is the appropriate use? American Journal of Respiratory and Critical Care Medicine 155: 1804-1814, 1996.

5. Bates JH. Diagnosis of tuberculosis. Chest 76 (suppl): 757-763, 1979.

6. Bonington A, Strang JIG, Klapper PE, Hood SV, Rubombora W, Penny M, Willers R, Wilkins EGL. Use of Roche AMPLICOR Mycobacterium tuberculosis PCR in early diagnosis of tuberculous meningitis. Journal of Clinical Microbiology 36:12511254, 1998.

7. Davies LE, Rastogi KR, Lambert LC, Skipper BJ. Tuberculous meningitis in the southwest United States: a community-based study. Neurology 43: 1775-1778, 1993.
8. Gyure KA, Prayson RA, Estes ML, Hall GS. Symptomatic Mycobacterium avium complex infection of the central nervous systems. A case report and review of the literature. Archives of Pathology and Laboratory Medicine 119: 836-839, 1995.

9. Kerr-Pontes LRS, Oliveira FAS, Freire CAM. Tuberculose associada à AIDS: situação de região do Nordeste brasileiro. Revista de Saúde Pública 31: 323-329, 1997.

10. Komachi H, Uchihara T, Saito $Y$, Takewaki S, Nagai R, Furukawa T. Successful treatment of atypical mycobacterial meningitis by fluoroquinolone. Journal of Neurological Sciences 142:170-172, 1996.

11. Kox, LFF, Kuijper S, Kolk, AHJ. Early diagnosis of tuberculous meningitis by polymerase chain reaction. Neurology 45: 22282232, 1995.

12. Lee BW, Tan JAMA, Wong SC, Tan CB, Yap HK, Low PS, Chia $\mathrm{JN}$, Tay JSH. DNA amplification by the polymerase chain reaction for the rapid diagnosis of tuberculous meningitis. Comparison of protocols involving three mycobacterial DNA sequences, IS6110, $65 \mathrm{kDa}$ antigen, and MPB64. Journal of Neurological Sciences 123: 173-179, 1994

13. Liu PYF, Shi ZY, Lau YJ, Hu, BS. Rapid diagnosis of tuberculous meningitis by a simplified nested amplification protocol. Neurology 44: 1161-1164, 1994. 
14. Machado LR, Livramento JA, Bydlowski SP, Bendit I, Bravo LM, Spina-França A. Polymerase chain reaction in the diagnosis of tuberculous meningitis. Arquivos de Neoropsiquiatria 52: 445446, 1994.

15. Nguyen LN, Kox LFF, Pham LD, Kuijper S, Kolk AHJ. The potential contribution of the polymerase chain reaction to the diagnosis of tuberculous meningitis. Archives of Neurology 53:771-776, 1996.

16. Pinto WP, Hadad DJ, Palhares MC, Ferrazoli L, Telles MA, Ueki SY, Santos MT, Placco AL, Sauaia N, Palaci M. Drug resistance of $M$. tuberculosis isolated from patients with HIV infection seen at an AIDS Reference Center in São Paulo, Brazil. Revista do Instituto de Medicina Tropical de São Paulo 38: 15-21, 1996.

17. Secretaria Estadual da Saúde, Centro de Vigilância Epidemiológica, Divisão de Tuberculose. Tuberculose: uma emergência mundial, São Paulo, 1995.
18. Sepkowitz KA, Raffalli J, Riley L, Kiehn TE, Armstrong D. Tuberculosis in the AIDS era. Clinical Microbiology Reviews 8: 180-199, 1995.

19. Seth P, Ahuja GK, Bhanu NV, Behari M, Bhowmik S, Broor S, Dar L, Chakraborty M. Evaluation of polymerase chain reaction for rapid diagnosis of clinically suspected tuberculous meningitis. Tubercle and Lung Disease 77: 353-357, 1996.

20. Shankar P, Manjunath N, Mohan KK, Prasad K, Behari M, Shriniwas, Ahuja GK. Rapid diagnosis of tuberculous meningitis by polymerase chain reaction. Lancet 337: 5-7, 1991.

21. Stauffer $F$, Haber $H$, Rieger A, Mutschlechner R, Hasenberger $P$, Tevere VJ, Young KKY. Genus level identification of mycobacteria from clinical specimens by using an easy-to-handle Mycobacterium-specific PCR assay. Journal of Clinical Microbiology 36: 614-617, 1998. 